\title{
The genus Crumenaria (Rhamnaceae, Gouanieae)
}

\author{
Roberto D. Tortosa, Adriana Bartoli \& Leonor Cusato
}

\section{Abstract}

TORTOSA, R. D., A. BARTOLI \& L. CUSATO (2013). The genus Crumenaria (Rhamnaceae, Gouanieae). Candollea 68: 267-277. In English, English and French abstracts.

A synopsis of the genus Crumenaria (Rhamnaceae, Gouanieae) is carried on and four species are recognized. Each species is described and illustrated, with the comprehensive synonymy and typification. The names Crumenaria choretroides Reissek, Crumenaria erecta Reissek, Crumenaria glaziovii Urb., Crumenaria lilloi Suess., and Crumenaria polygaloides Reissek are lectotypified. A key and a distribution map of the genus are provided.

\section{Key-words}

RHAMNACEAE - GOUANIEAE - Crumenaria - Central America - South America - Taxonomy

\section{Résumé}

TORTOSA, R. D., A. BARTOLI \& L. CUSATO (2013). Le genre Crumenaria (Rhamnaceae, Gouanieae). Candollea 68: 267-277. En anglais, résumés anglais et français.

Un synopsis du genre Crumenaria (Rhamnaceae, Gouanieae) est proposé avec quatre espèces reconnues. Chaque espèce est décrite et illustrée, avec sa synonymie et la typification de tous les noms. Les noms Crumenaria choretroides Reissek, Crumenaria erecta Reissek, Crumenaria glaziovii Urb., Crumenaria lilloi Suess. et Crumenaria polygaloides Reissek sont lectotypifiés. Une clé et une carte de répartition du genre sont fournies.

\footnotetext{
Address of the authors: Laboratorios de Botánica “L. R. Parodi”, Facultad de Agronomía, Universidad de Buenos Aires, Av. San Martín 4453, C1417DSE Buenos Aires, Argentina. E-mail (RDT, Consejo Nacional de Investigaciones Científicas y Técnicas): tortosa@agro.uba.ar 
Crumenaria Mart. is a genus of Rhamnaceae from Central and South America (Fig. 1-2), notable for the herbaceous habit, including annual and perennial herbs, in which the flowers have inferior ovary and the fruits are 3-seeded schizocarps, with winged membranous diaspores. For the characters of flowers and fruits, it is accommodated in the tribe Gouanieae Endl. (RICHARDSON \& al., 2000), with the genera Alvimiantha Grey-Wilson, Gouania Jacq., Johnstonalia Tortosa, and Reissekia Endl., all them with vine habit.

MARTIUs (1826-1827) established the genus based on a slender annual herb from Brazil, Crumenaria decumbens Mart. Later, several species, varieties and forms were described in the genus by ReISSEK (1861), URBAN (1898), CHODAT \& Hassler (1903), Hassler (1915), Suessenguth (1939), and STANDLEY (1940).

SuESSENGUTH (1953) recognized 6 species for the genus Crumenaria: the type species, $C$. decumbens, $C$. choretroides Reissek (with $C$. erecta as a synonym), $C$. diffusa Suess., C. glaziovii Urb., C. lilloi Suess., and C. polygaloides. TortosA $\&$ al. (2013), before the treatment of the Rhamnaceae for "Flora del Paraguay" (CusATO \& TORTOSA, 2013), provided a comprehensive synthesis on the typification of the numerous names published by CHODAT (1903) and HASSLER (1915) and their taxonomic value.

In the present synopsis we recognize 4 species in the genus, one annual and the other three perennial.

\section{Crumenaria Mart., Nov. Gen. Sp. P1. 2: 68. 1826.}

Type species: Crumenaria decumbens Mart.

Annual or perennial herbs, leafy or almost leafless; leaves alternate, with stipules. Inflorescence a 1-14 flowered umbel, terminal or axilar. Flowers pedicellated, with campanulate or turbinate-campanulate floral tube. Calix with 5 sepals triangular, erect. Petals 5, cucullate, clawed, erect. Disc absent. Stamens opposite and hidden within the petals, with thread-like filaments with curved apex, anthers dorsifixed, cordate, obtuse, with 2 loculi, and lateral-longitudinal dehiscence. Ovary inferior, obconic, trilocular, with solitary ovules in each loculus; style included or exserted, 3-toothed or divided in three branches; stigma obtuse. Fruit 3-seeded schizocarps, with winged membranous diaspores. Seeds obovate, dorsally convex, ventrally angled, tegument corneous, lustrous, endosperm thin, cotyledons elliptic, compressed, radicle very short.

\section{Key to the species of Crumenaria}

1. Inflorescence axillary ………………………….............. 2

1a. Inflorescence terminal. Perennial rhizomatous herbs .... 3

2. Annual herbs. Flowers solitary or paired ... C. decumbens

2a. Perennial herbs, with rhizome and xylopodium. Flowers grouped 4 to 8

C. glaziovii

3. Floral tube glaber. Plants with junciform-polygonoid habit, with scale-like or small linear leaves C. erecta

3a. Floral tube pubescent. Plants with leaves ovate to broadly elliptic

C. lilloi

1. Crumenaria decumbens Mart., Nov. Gen. Sp. Pl. 2: 69. 1827 (Fig. 1-3).

Typus: Brazil. Piauí: Oeiras, Ilha, s.coll., s.d., (holo-: M [M0147083] digital image!).

$=$ Crumenaria diffusa Suess. in Lilloa 4: 134. 1939. Typus: Ceará: Cedro, VI.1933, Luetzelburg 25788 (holo-: M, digital image!) syn. nov.

$=$ Crumenaria steyermarkii Standl. in Publ. Field Mus. Nat. Hist., Bot. Ser. 22: 156. 1940. Typus: Jutiapa: plains and swampy ground along railroad between Agua Blanca and Amatillo, 950-, 24.X.1939, Steyermark 30448 (holo-: F [F0068132F], digital image!; iso-: NY [NY00233279]!) syn. nov.

Slender annual leafy herb up to $30(-50) \mathrm{cm}$, with thin roots. Stems erect or decumbent, subangled, striate, ca. diam., much ramified, with sparse, appressed hairs. Leaves membranous; stipules linear-elliptic, 1- long, apex acute, margin ciliate; petiole glaber or pubescent 2-; blade ovate, elliptic ovate, or subtriangular, 1- $\times 1-$, margin entire, subcrenate, or with minute teeth, ciliate, base cordate, apex somewhat obtuse or acuminate, mucronate, 3(-5)-nerved at the base, adaxial surface glaber, abaxial surface with appressed hairs on the nerves. Inflorescences axillary, 1-2 flowered; peduncles 6-20 mm, glaber. Flowers white; pedicels 1-, glabrous or pubescent, receptacle with long, thin, rigid appressed hairs; floral tube turbinate-campanulate, 1- long, glaber; sepals 0.8- long; petals 0.6- long; stamens with filaments 0.3- long and anthers long; style single or divided. Fruit 4 - long $\times$ broad, surface with sparse hairs, apex scarcely emarginate, margin ciliate.

Iconography. - MARTIUS (1826-1827): tab. 160 and Figure 3.

Distribution and habitat. - Crumenaria decumbens has been collected in Bolivia (JøRGENSEN \& al., 2013), Brazil (TORTOSA, 2008; de Lima, 2010), Guatemala (STANDLEy \& STEYERMARK, 1949), and Honduras (MolinA, 1975), in sandy or rocky soils, in margin of subhumit forests, and as a weed in cornfields and roadsides, at elevation from 300 to $900 \mathrm{~m}$. 


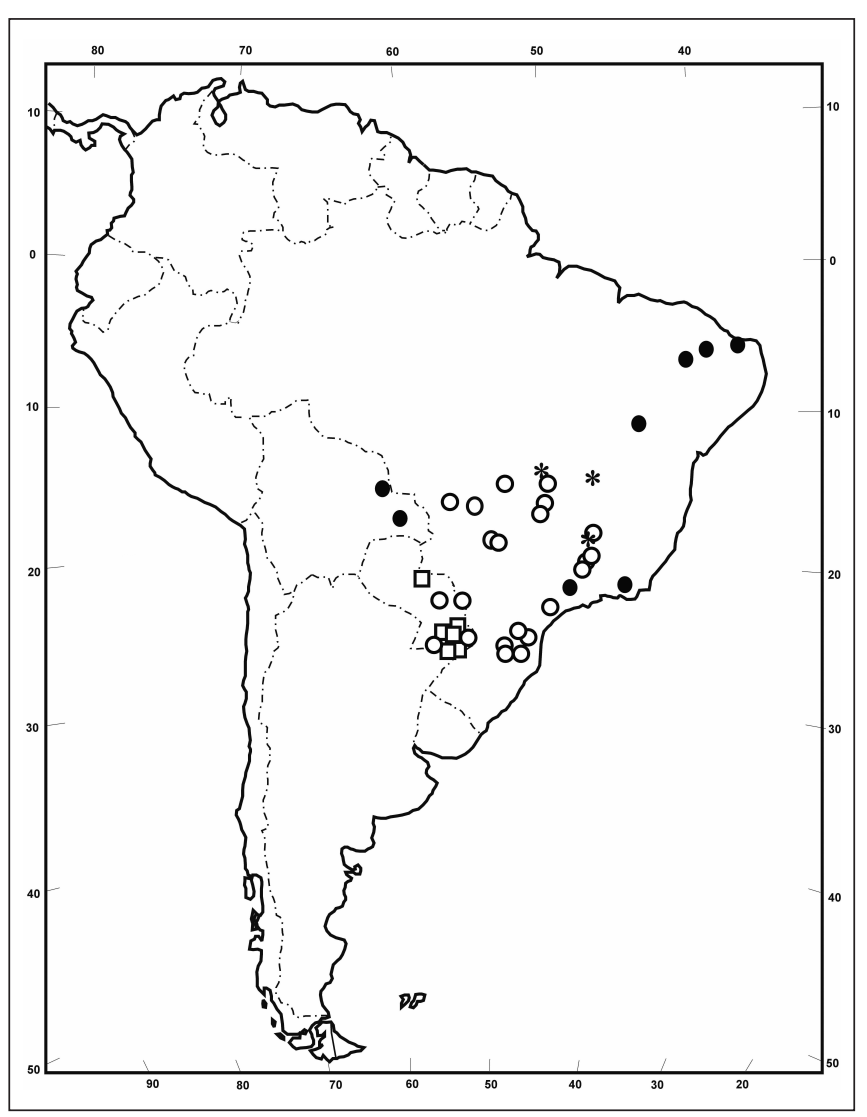

Fig. 1. - Geographic distribution of Crumenaria decumbens Mart. (0) (South American specimens); C. erecta Reissek (O); C. glaziovii Urb. (*); C. lilloi Suess. ( $\square$ ).

Phenology. - Crumenaria decumbens flowers from August to May.

Etymology. - The name of C. decumbens is taken from its decumbent habit.

Discussion. - Crumenaria decumbens is a quite distinct slender annual herb, different from the other species of the genus, which are perennial. Its roots smell like menthol (Abbott 16283 and Abbott \& Mostacedo 16078).

Crumenaria diffusa and C. steyermarkii match all the diagnostic characters of $C$. decumbens, although the stems are more erect in the type of $C$. diffus $a$ and leaves are slightly wider in that of C. steyermarkii.

Additional specimens examined. - Bolivia. Santa Cruz: Chiquitos, Roboré, E of Roboré River and N of Avenida del Ejército and railroad track, 4.II.1995, Abbott \& Mostacedo 16078 (BAA, NY). Nuflo de Chavez: Lomerio, ca. south of Concepción to Las Trancas community, then ca. to north on access "road", 21.II.1995, Abbott 16283 (MO, digital image); camino de Concepción a San Antonio de Lomerio, a SE de Concepción, 23.I.2004, Silis Neffa \& al. 1177 (CTES).

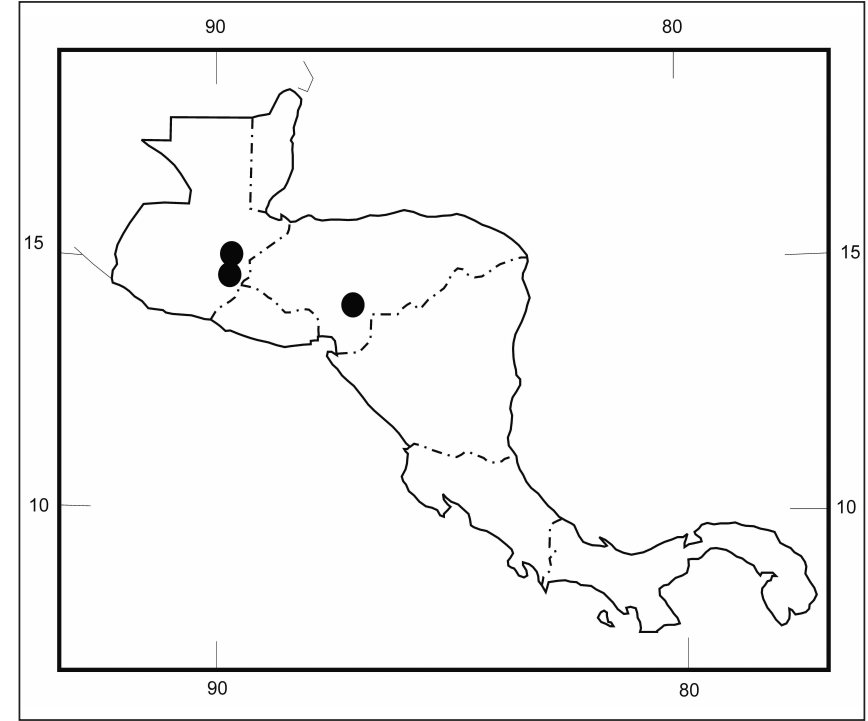

Fig. 2. - Geographic distribution of Crumenaria decumbens Mart. (()) (Central American specimens).

BRAZIL. Bahia: Barreiras, valley of the Rio das Ondas, ca. W of Barreiras, Rio das Ondas, 6.III.1971, Irwin \& al. 31660 (NY). Piauí: no date, Gardner 2314 (NY). Rio de Janeiro: Serra da Estrela, 18361841, Gardner 2314 (NY). Rio Grande do Norte: pau dos Ferros, sítio Boi Morto, 17.V.1984, Sarmento \& Santino de Asis 765 (NY).

GUATEMALA. Jutiapa: vicinity of Jutiapa, ca., 24.X- 5.XI. 1940, Standley 75343 (MO, NY); vicinity of Jutiapa, ca., 24.X- 5.XI.1940, Standley 75047 (NY). Zacapa: near the electric plant of Río Hondo, base of Sierra de las Minas, 11.X.1940, Standley 73976 (NY).

Honduras. Francisco Morazán: on rocky roadside hill of Támara Valley, vicinity of Río del Hombre, 28.IX.1969, Molina R. \& Molina 24543 (MO, NY); vicinity of El Zamorano, 780-, 317.VIII.1947, Standley 12066 (NY, PH); along río Caparroza, above El Zamorano, IX-X.1948, Standley 12795 (NY).

2. Crumenaria erecta Reissek in Endl., Nov. Stirp. Dec.: 28. 1839 (Fig. 1, 4).

Lectotypus (designated here): BRAZIL. Minas Geráis: Rio J. Pohl s.n. (BR [BR0000005296026] digital image!; iso-: BR [BR0000005295937] digital image!).

$=$ Crumenaria choretroides Reissek in Mart., Fl. Bras. 11(1): 114. 1861. Lectotypus (designated here): BRAZIL. Minas Geráis: Serro do Frio, Martius s.n. (M [M01470 84] digital image!) (synonymized by SuESSENGUTH, 1939).

$=$ Crumenaria polygaloides Reissek in Mart., Fl. Bras. 11(1): 113. 1861. Lectotypus (designated here): Brazil: no date, Sellow s.n. (US, [US00094533] digital image!) syn. nov. 
= Crumenaria polygaloides var. lancifolia Chodat in Bull. Herb. Boissier ser. 2, 3: 542. 1903. = Crumenaria polygaloides f. lancifolia (Chodat) Hassl. in Repert. Spec. Nov. Regni Veg. 14: 165. 1915. = Crumenaria polygaloides var. glabrescens Hassl. in Repert. Spec. Nov. Regni Veg. 14: 165. 1915 [nom. illeg.]. Typus : Paraguay. Cordillera: in valle fluminis Y-acá in campis pr. Valenzuela, I.1900, Hassler 6937 (holo-: G [G00228941]!) (synonymized by TORTOSA, 2008).

= Crumenaria choretroides var. hirtella Hassl. in Repert. Spec. Nov. Regni Veg. 14: 165. 1915. Typus: Amambay: Sierra de Amambay in campis arenosis Esperanza, IX.1907-1908, Hassler \& Rojas 10637 (holo-: G [G002 28939]!) (synonymized by TORTOSA, 2008).

Perennial, almost leafless herb, 30-, with a ligneous rhizome, ca. diam. Stems erect, terete and striate, or subangled, 0.1- diam., much ramified at the base, glaber or with short hairs. Leaves scale-like or linear-elliptic, lesser than long, with stipules linear, briefly petiolate, blade 1-3-nerved, margin entire, glaber or with long sparce hairs on both surfaces. Inflorescences terminal, ramified, each branch 2-, ending in a 2-14 flowered umbel. Flowers white, with pedicels 3-, glaber or scarcely pubescent; receptacle glaber or loosely hirsute; floral tube campanulate, 2- long, glaber; sepals 0.7-long; petals ca. long; stamens with filaments long and anthers long; style long, divided at the apex. Fruit 6long $\times 5.5$ - broad, reticulate, glaber.

Iconography. - REISSEK (1861): tab. 41 and Figure 4.

Distribution and habitat. - Crumenaria erecta has been collected in the south of Brazil and east of Paraguay (TORTOSA, 2008; de LiMA, 2010; CUSATO \& TORTOSA, 2013), at elevations from 500 to $1300 \mathrm{~m}$.

Phenology. - Crumenaria erecta flowers from August to May.

Etymology. - The specific epithet of C. erecta is taken from its erect habit.

Discussion. - The priority of C. erecta and the treatment of some Paraguayan taxa by HASSLER (1915) are discussed by TortosA \& al. (2013). Crumenaria erecta differs from the other species of the genus by its almost leafless habit. Some specimens of this species show fasciation in the stems; $C$. choretroides was based on two of such gatherings (see also Glaziou 20850, Hassler 10637, Irwin 7944, and Weddell s.n.).

We choose as lectoype of $C$. erecta one of the specimens at BR, which matches the protologue, and for $C$. choretroides the syntype from Serro de Frio at $\mathrm{M}$ which is representative of this taxon. In the case of $C$. polygaloides, the type specimen at B (negative at F [barcode] F0BN005862 digital image!) was destroyed during World War II, so we choose as lectotype the isotype at US.
REISSEK (1861) differentiated C. erecta, C. choretroides, and C. polygaloides by the pubescence (glaber or pubescent) and the section (terete, compresed, or fasciated) of stems, the size of leaves, and the number of flowers of the inflorescences, all characters variable within this taxon.

Additional specimens examined. - BRAZIL: s.l., Glaziou 20850, [sub nom. Crumenaria angulata URBAN (C, photo NY!). Brazil Central, no date, Weddell s.n. (NY). Distrito Federal: Margem de estrada, terra entre Escola Fazendária e Paranoá, 26.VIII.1980, Heringer \& al. 5358 (NY); Brasilia, Hôrto do Guará, 10.V.1960, Heringer $8641 / 835$ (NY); Brasilia (Torre de Microondas-Sul), 25.IX.1980, Heringer 17912 (NY); Brasilia, Trevo de Unaí, 14.X.1980, Heringer \& Salles 17931 (NY); Chapada da Contagem. 4.IX.1965, Irwin \& al. 7944 (NY); limit Parque do Gama and Goiás, 15.X.1963, Maguire \& al. 57079 (NY); Fazenda Agua Limpa, University of Brasilia, field station, near Vargem Bonita c. SSW of Brasilia, TV tower, 1.XI.1978, Ratter \& al. R. 4238 (NY). Goiás: Mun. Alto Paraíso, 26.IX.1995, Fonseca \& Neto 572 (BAA). Rio San Francisco, Garder 3422 (BR [5295609]!; K [531971]!); Mun. Cristalina, Parque Nacional Chapada dos Veadeiros, 14.VIII.1980, Hatschbach 43105 (CTES); Luziânia, rodovia para Brasilia, 6.X.1980, Heringer 17891 (NY); ca. E of Caiapônia on road to Jataí, serra do Caiapó, 18.X.1964, Irwin \& Soderstrom 6985 (NY). Mato Grosso: R10, c. SW of Base Camp, 20.IX.1968, Harley \& Souza 10171 (NY); ca. N of Xavantina, 9.X.1964, Irwin \& Soderstrom 6702 (NY); Chapada Guimaraes, vicinity big waterfall Veu das Noivas, 24.IX.1988, Kral \& al. 75058 (NY); Mato Grosso, July 1892, Kuntze s.n. (NY); Serra da Saudade, camp beyond Alto Araguaia, Brasilia-Acre Highway, 26.VIII.1963, Maguire \& al. 56349 (NY); just above Veu da Noiva, 16.X.1963, Prance \& al. 19069 (NY); campo at S end of R11, Base Camp Square, 6.VIII.1968, Richards 6606 (NY). Mato Grosso do Sul: Mun. Ponta Pora, by the bridge on the R. Santa Maria, 25.X.1986, Pedersen 14734 (CTES). Minas Geráis: Paraopeba, 25.XI.1965, Goodland 202 (NY); Serra do Espinhaço, ca. N.E. of Francisco Sá, on road to Salinas, 10.II.1969, Irwin \& al. 23024 (NY); Gouveia, Fazenda do Sr. Everaldo, estrada para o Garimpo, 11.IX.1986, de Menezes \& al. SPF44 792 (NY); Diamantina, Barão, upper slopes Serra de Capão, 21.V.1931, Mexia 5877 (NY, PH); Uberaba, 28.X.1848, Regnell III.383 (NY); Mun. Ituintal, 16.X.1949, Smith s.n. (NY); Lagoa Santa, s.d., Warming s.n. (NY). Paraná: parque Vila Velha, 27.X.1989, Cervi \& Hatschbach 2926 (NY); Rio Tibagi, 5.XI.1964, Dombrowski 833 (CTES); 11.X.1976, Dombrowski 6320 (CTES); Desvío Ribas, 29.XI.1910, Dusén 10866 (NY, PH, SI); Mun. Senges, Serra do Mocambo, 19.IX.1975, Hatschbach 37224 (CTES, NY); Ponta Grossa, Villa Velha, 3.XI.1928, Hoehne 23349 (CTES, SI, NY); 9.VIII.1962, Moreira 302 (CTES); Palmeira, Recanto dos Papagaios, 28.X.1996, Ribas \& da Luz 1569 (NY). São Paulo: Itapetininga, NE da Vila Alabert em linha reta, km 145 da estrada Sã o Paulo-Itapetininga (S. P. 4), 2.X.1959, de Campos 73 (NY); MojiGuaçu, Campos das Sete Lagôas, fazenda Campininha, just $\mathrm{N}$ of rio Moji-Guaçu, NNE of Padua Sales, about NW of city of Moji-Mirim, 22.IX.1969, Eiten \& Eiten 2370 (NY); NNE of Padua Sales, about NW of city of Moji-Mirim, 22.IX.1960, Eiten \& Eiten 2374 (NY); Moji-Guaçu, fazenda Campininha, 3.X.1977, Jung-Mendacolli \& al. 65 (NY).

Paraguay: see Cusato \& Tortosa (2013). 


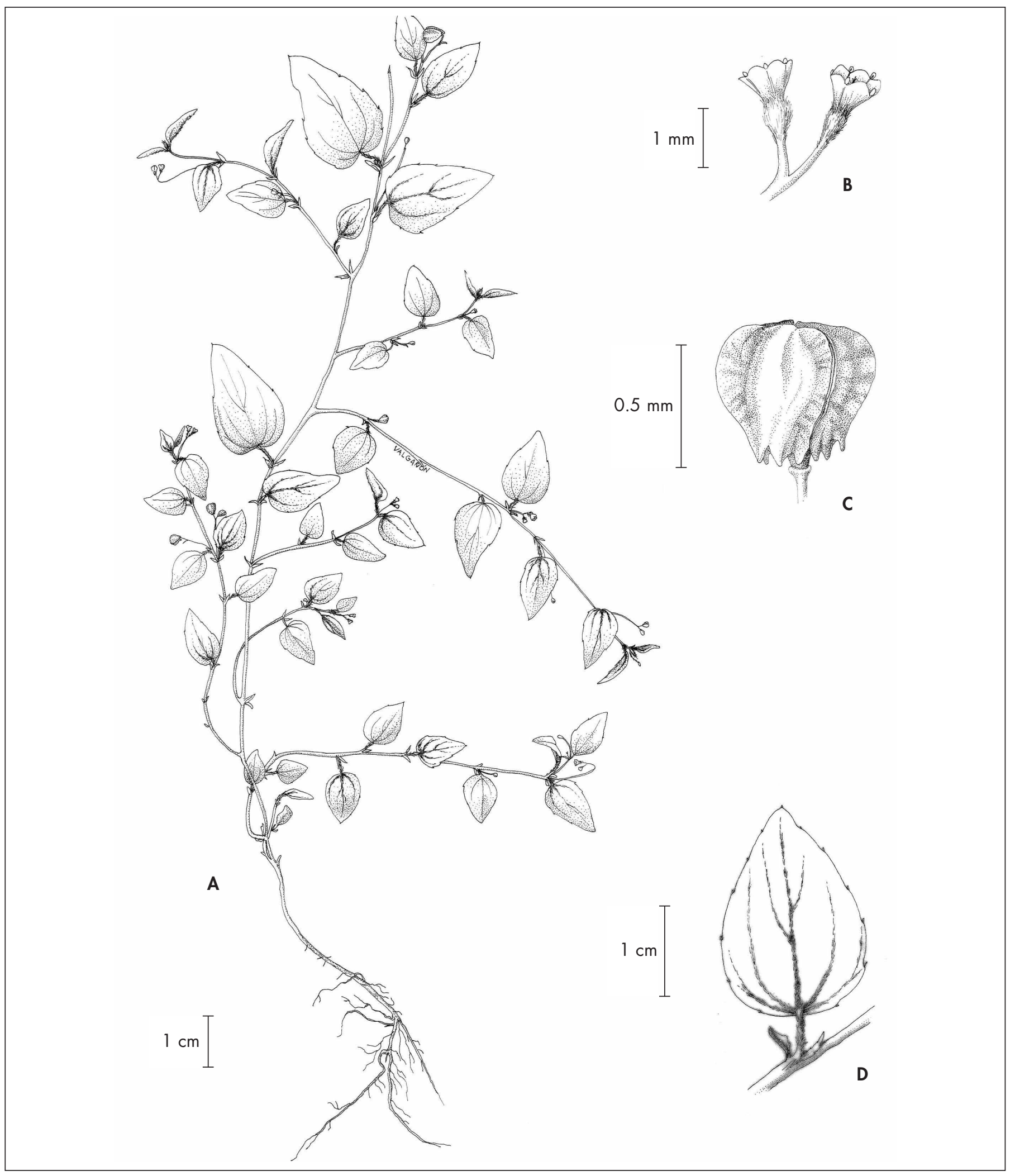

Fig. 3. - Crumenaria decumbens Mart.

[Abbot \& Mostacedo 16078, BAA] [Drawn by Norma Valgañon] 
3. Crumenaria glaziovii Urb. in Bot. Jahrb. Syst. 25, Beibl. 60: 1. 1898 (Fig. 1, 5).

Lectotypus (designated here): BrazIL. Goiás: inter Cabeceiras do Rio Sambambaia et Le Pouzo de Barbatimao, Glaziou 20848 (BR [BR0000005314171] digital image!; iso-: K [K000531970] digital image!, R [R000074467] digital image!, S [S-R-9570] digital image!).

Perennial herb, 10-, with rizhome and xylopodium. Stems spreading, terete, striate, 0.5 - diam., with short hairs. Leaves with stipules elliptic; 3 - long; petiole 1.5- long; blade broadly elliptic or elliptic, 1-2.5 $\times 0.5-$, margin entire, apex apiculate, adaxial surface glaber, abaxial surface glaber or with appressed hairs on the nerves. Inflorescences axillary, 4-8-flowered, peduncles 3.5- long. Flowers white, with pedicels 1-, pubescent; receptacle with rigid appressed hairs. Floral tube campanulate, long, glaber; sepals ca. long; petals ca. long; stamens with filaments long and anthers long; style ca. divided at the apex. Fruit not seen.

Distribution and habitat. - Crumenaria glaziovii grows in grazing areas of the states of Goiás and Minas Geráis of Brazil (de LimA, 2010), at elevations from 600 to $1050 \mathrm{~m}$.

Phenology. - Crumenaria glaziovii flowers in October and November.

Etymology. - Crumenaria glaziovii was named in honor of Auguste François Marie Glaziou (1828-1906), a French botanist and landscape designer, who collected the type specimen.

Discussion. - Crumenaria glaziovii is related to C. decumbens with which it shares axillary inflorescences and slender stems, but differs in its perennial habit.

The holotype at B (negative at F [barcode] F0BN005861 digital image!) was destroyed during World War II; we choose the isotype at BR as lectotype which matches the diagnostic characters.

Additional specimens examined. - BRAzIL. Goiás: Chapada dos Veadeiros, ca. N.W. of Veadeiros, road to Cavalcante, 22.X.1965, Irwin \& al. 9478 (NY). Minas Geráis: Sacramento, Parque Nacional da Serra da Canastra, estrada São Roque de Minas - Sacramento, da Portaria de São Roque de Minas, 7.XI.2002, Pontes \& al. 535 (NY).
4. Crumenaria lilloi Suess. in Lilloa 4: 134. 1939 (Fig. 1, 6). Lectotypus (designated here): Argentina. Misiones: Santa Ana, 16.X.1912, F. Rodriguez 12549 (M, digital image!; iso-: LIL [LIL001701]!; SI!).

$=$ Crumenaria polygaloides var. aurea Chodat in Bull. Herb. Boissier ser. 2, 3: 543. 1903. = Crumenaria polygaloides subsp. paraguariensis Hassl. in Repert. Spec. Nov. Regni Veg. 14: 165. 1915. Typus: ParaguaY. Canendiyú: in campo pr. Ipé-hú, Sierra de Maracayú, X.1898-1899, Hassler 5186 (holo-: G [G00306598]!) (synonymized by TORTOSA \& al., 2013).

$=$ Crumenaria polygaloides var. foliosa Chodat in Bull. Herb. Boissier ser. 2, 3: 542. 1903. Typus: Paraguay. Canendiyú: in campis pr. Igatimí, XI.1898-1899, Hassler 5467 (holo-: G [G00228951]!) (synonymized by TORTOSA, 2008).

$=$ Crumenaria polygaloides f. glabrata Chodat in Bull. Herb. Boissier ser. 2, 3: 543. 1903. =Crumenaria polygaloides var. discolor Hassl. in Repert. Spec. Nov. Regni Veg. 14: 165. 1915. Typus: Paraguay. San Pedro: in campis siccis in regione cursus superioris fluminis Apa, XII.1901-1902, Hassler 8271 (lecto-: G [G00228952]!) (synonymized by TORTOSA, 2008).

Perennial leafy herb, 20-, with a ligneous rhizome, 0.5diam. Stems erect or decumbent, terete and striate, or subangled, 0.1- diam., ramified at the base, with short hairs. Leaves with stipules elliptic, 0.3 - long, pubescent; petiole 1.5; blade ovate or broadly-elliptic, 3 - long $\times 1$.2- broad, apex subacute or obtuse, base obtuse, margin entire or crenateserrate, pubescent on both surfaces or with the upper epidermis glaber and de basal epidermis with hairs on the nerves. Inflorescence terminal, peduncle 3.5- long, sometimes ramified, with branches ca. 0.5- long, ending in 4-9-flowered umbels. Flowers white or yellowish, with pedicels 3-; receptacle pubescent; floral tube campanulate, long, pubescent; sepals ca. long; petals ca. long; stamens with filaments long and anthers long; style long, 3-divided at the apex. Fruit $0.6-$ long $\times 0.8$ - broad, reticulate, glaber.

Distribution and habitat. - Crumenaria lilloi grows in grasslands in Paraguay, South Brasil and NE of Argentina (TORTOSA, 2008; CusATO \& TORTOSA, 2013), at elevations from 120 to $320 \mathrm{~m}$.

Phenology. - Crumenaria lilloi flowers from September to March.

Etymology. - Crumenaria lilloi was named in honor of Miguel Lillo (1862-1931), Argentine botanist and naturalist. 


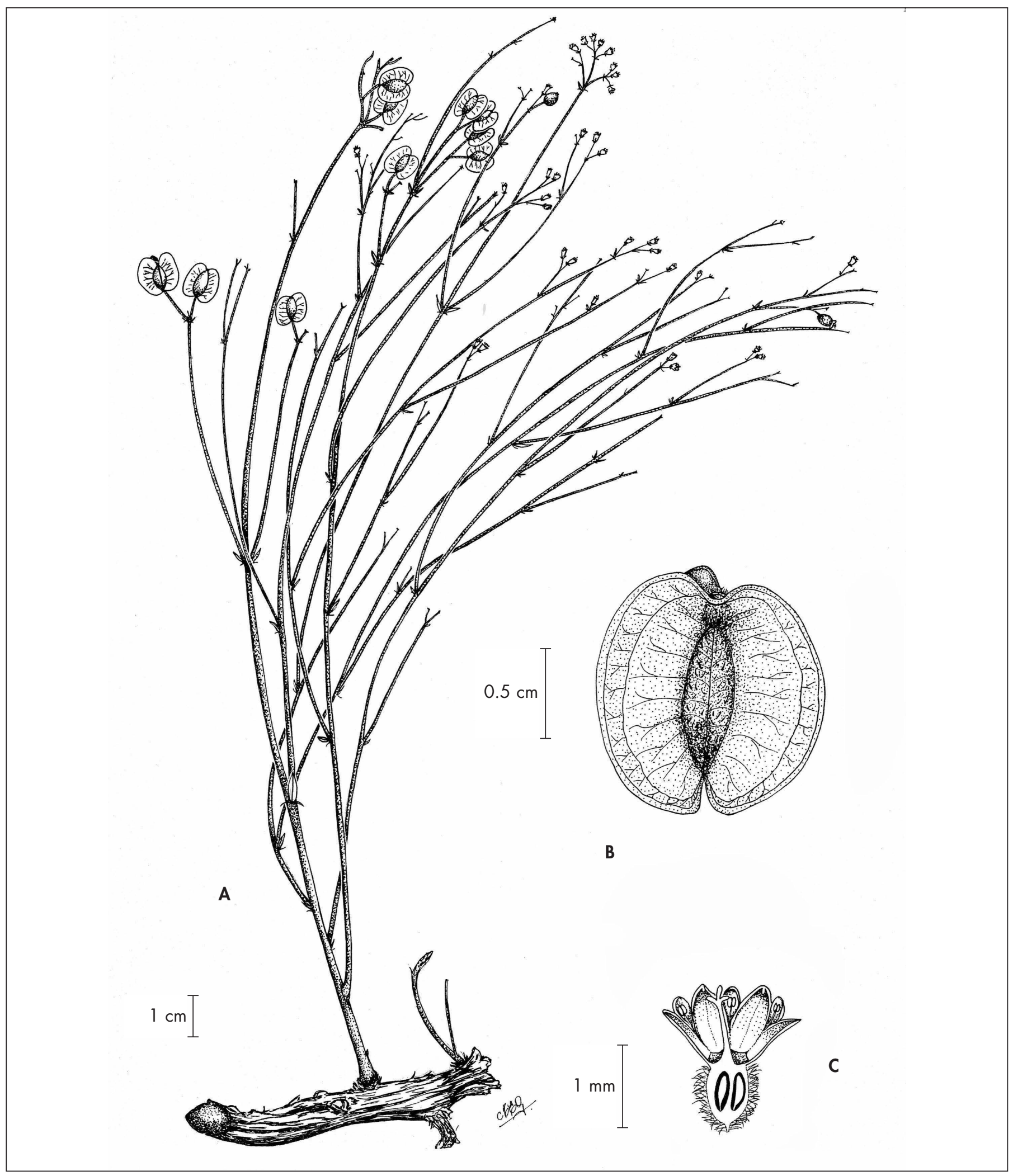

Fig. 4. - Crumenaria erecta Reissek. A. Habit; B. Fruit; C. Flower. [Hassler 10637a, G] [Drawn by María Eugenia Gallegos] 


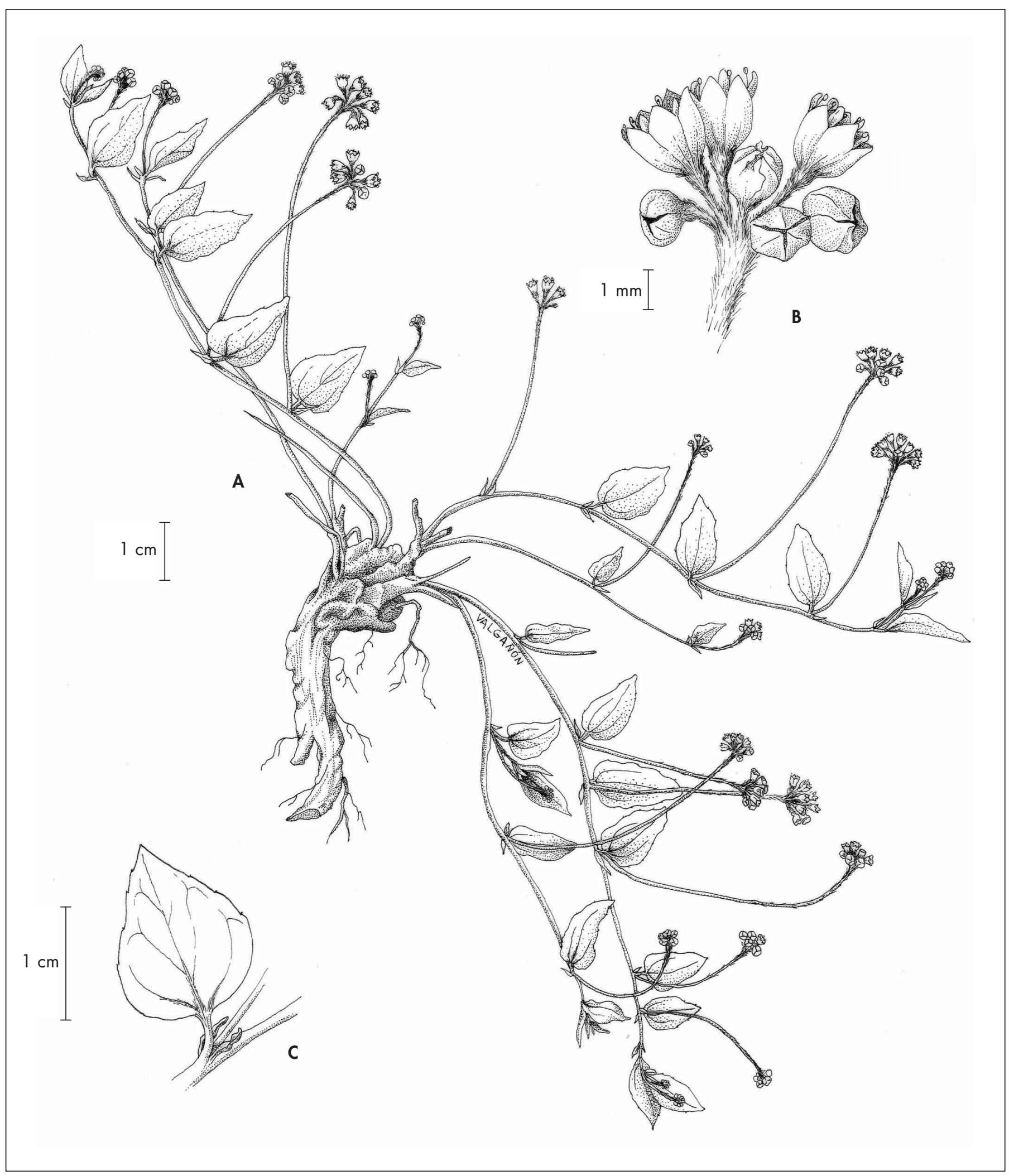

Fig. 5. - Crumenaria glaziovii Urb. A. Habit; B. Flower.

[Pontes 535, NY] [Drawn by Norma Valgañon] 


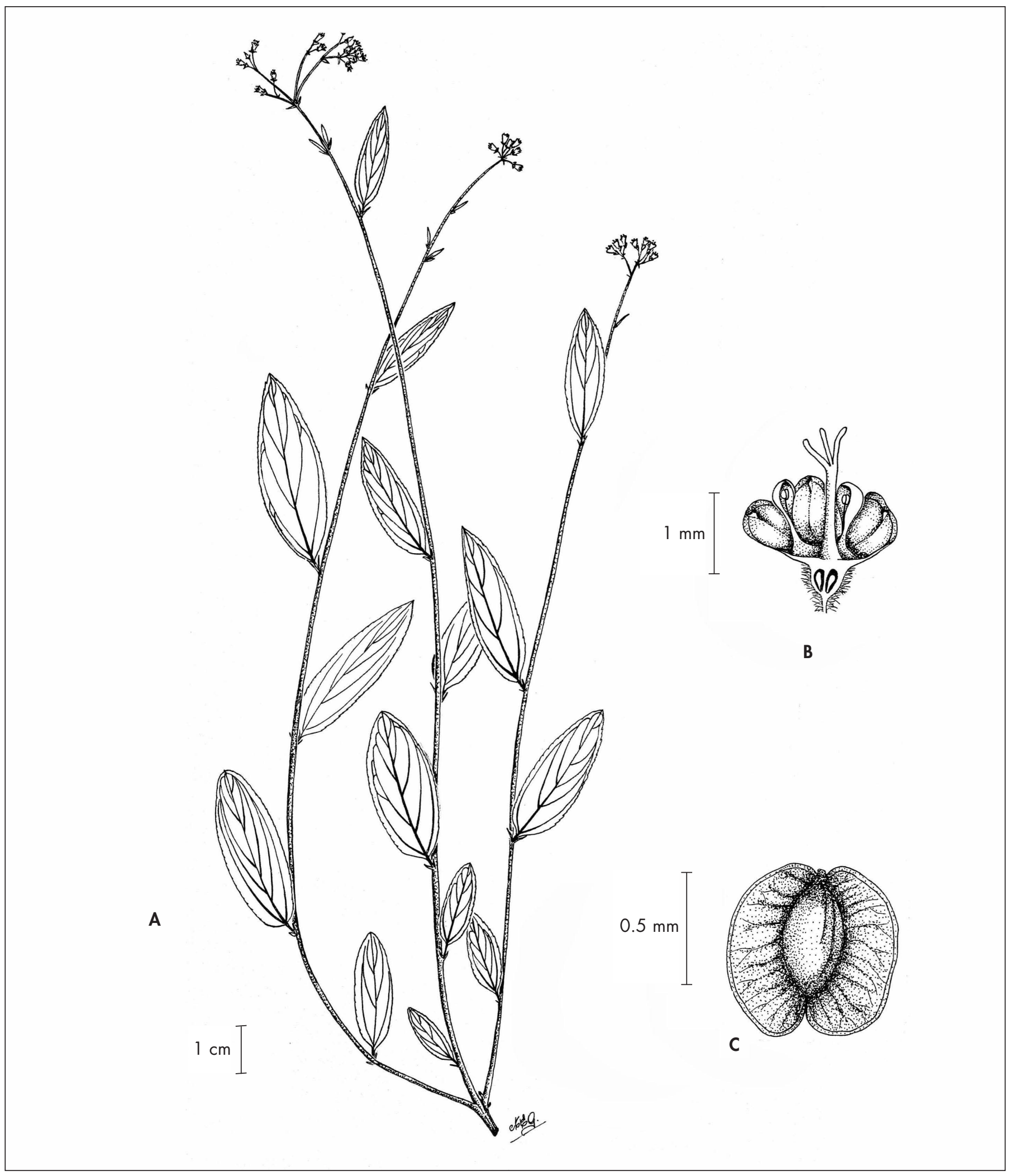

Fig. 6. - Crumenaria lilloi Suess. A. Habit; B. Fruit; C. Flower.

[A-B: Hassler 8271, G; C: Hassler 4549, G] [Drawn by María Eugenia Gallegos] 
Discussion. - In the original description of C. lilloi, SUESSENGUTH pointed out that the materials on which he based his description were both at "herb. Munchen and Inst. Lillo, Tucumán". We choose the specimen at M as lectotype because it is more complete (two fertile stems vs. one fertile stem and three sterile in the specimen at LIL).

Chodat (1903), who studied the genus Crumenaria in Paraguay, considered that all the materials collected by Emil Hassler in that country belonged to the Brasilian species C. polygaloides $(=$ C. erecta). On account of differences in the shape of leaves and in the general pubescence of the plants, he established three varieties and a form. Later, HASSLER (1915) tried a Paraguayan taxa's reappraisal of his own. A synthesis on the typification of the numerous names involved and their taxonomic value is presented by TORTOSA \& al. (2013) before the treatment of the Rhamnaceae for "Flora del Paraguay" (Cusato \& TORTOSA, 2013).

Additional specimens examined. - Argentina. Corrientes: Ituzaingó: Ituzaingó, Rincón Ombú Chico, 11.X.1980, Schinini 20932 (CTES); Ea. Puerto Valle, 23.X.1967, Myndel Pedersen 8678 (NY); San Miguel, NE de San Miguel, rutas 5 y 117, Ea. Curuzú Laurel, 9.XI.1981, Schinini 21633 (CTES). Misiones: A. de las Llamas, X.1901, s.coll. (BAB). Bonpland, arroyo Mártires Chico, 16.I.1976, Krapovickas 28776 (CTES). San Ignacio: San Ignacio, 11.X.1975, Zardini \& al. 704 (SI); San Ignacio, 21.IX.2000, Múlgura de Romero \& al. 2191 (SI).

Paraguay: see Cusato \& Tortosa (2013).

\section{Acknowledgements}

The authors gratefully acknowledge the assistance of the curators of CTES, G, LIL, LP, M, MO, NY, PH, and SI, and the support provided by the Universidad de Buenos Aires and Consejo Nacional de Investigaciones Científicas y Técnicas. We also thank the artists María Eugenia Gallegos and Norma Valgañon for the drawings.

\section{References}

Chodat, R. (1903). Rhamnaceae. In: Chodat, R. \& E. Hassler, Plantae Hasslerianae. Bull. Herb. Boissier ser. 2, 3: 541-542.

Cusato, L. I. \& R. D. Tortosa (2013). Rhamnaceae. In: Ramella, L. \& P. Perret (ed.), Fl. Paraguay 44. Conservatoire et Jardin botaniques de la Ville de Genève.

de Lima, R. B. (2010). Rhamnaceae. In: ForzzA, R. C. \& al. (ed.), Catálogo de plantas e fungos do Brasil: 1541-1542. Jardim Botânico do Rio de Janeiro.

Hassler, E. (1915). Ex herbario Hassleriano: Novitates paraguarienses XX. Repert. Spec. Nov. Regni Veg. 14: 161-180.

Jørgensen, P. M., M. H. NeE \& S. G. Beck (ed.) (2013). Catálogo de las plantas vasculares de Bolivia. Monogr. Syst. Bot. Missouri Bot. Gard 9.

Martius, C. F. P. (1826-1827). Crumenaria. Nov. Gen. Sp. Pl. 2: 6870.

Molina, R. A. (1975). Enumeración de las plantas de Honduras. Ceiba 19: 1-118.

Reissek, S. (1861). Rhamnaceae. In: C. F. P. Martius, Fl. Bras. 11(1): 81-116.

Richardson, J. E., M. F. Fay, Q. C. B. Cronk \& M. W. Chase (2000). A revision of the tribal classification of Rhamnaceae. Kew Bull. 55 : 311-340.

Standley, P. C. (1940). Studies of American plants-XI. Publ. Field Mus. Nat. Hist., Bot. Ser. 22: 133-218.

Standley, P. C. \& J. A. Steyermark (1949). Rhamnaceae. Flora of Guatemala - Part VI. Fieldiana, Bot. 24: 277-293.

Suessenguth, K. (1939). Ueber einige amerikanische Amaranthaceae und Rhamnaceae. Lilloa 4: 125-135.

Suessenguth, K. (1953). Rhamnaceae. In: Engler, A. \& K. Prantl (ed.), Nat. Pflanzenfam. ed. 2, 20d: 7-173. Duncker \& Humboldt, Berlin.

Tortosa, R. D. (2008). Rhamnaceae. In: Zuloaga, F. O., O. MorRONE \& M. J. Belgrano (ed.), Catálogo de las plantas vasculares del Cono Sur (Argentina, Sur de Brasil, Chile, Paraguay y Uruguay). Monogr. Syst. Bot. Missouri Bot. Gard. 107: 28392852 .

Tortosa, R. D., L. Ramella \& P. Perret (2013). Tipificaciones y sinónimos nuevos en el género Crumenaria Mart. (Rhamnaceae) de la flora del Paraguay. Candollea 68: 74-75.

URBAN, I. (1898). Plantae novae americanae imprimis Glaziovianae. II. Rhamnaceae. Bot. Jahrb. Syst. 25, Beibl. 60: 1-2. 1898. 